\title{
Evaluation and chemical treatment of organic pollution discharged into the River Nile: Case Study
}

\author{
Mohamed H. Abdo' ${ }^{1}$; Mohamed H. El-Sharkawy ${ }^{2}$; Mokhles H. El-Kordy ${ }^{2}$ and \\ Mostafa E. Mostafa ${ }^{3}$ \\ 1- National Institute of Oceanograpy and Fisheries - NIOF, \\ 2- Chemistry Administration \\ 3- Faculty of Science, Benha University, Egypt. \\ Corresponding author:mh_omr@yahoo.com
}

\section{ABSTRACT}

The present study deals with the evaluation of the organic pollution by determination of COD in the effluents discharged from Egyptian Sugar and Integrated Industries Company (ESIIC) into the River Nile without any treatment. Then, how we can treat the organic pollution? through the decrease in COD value by use (AC) Activated Carbon, $\mathrm{H}_{2} \mathrm{O}_{2}$, UV and $\mathrm{UV} / \mathrm{H}_{2} \mathrm{O}_{2}$ effects. The obtained results revealed that the concentration value of COD $36294 \mathrm{mg} / \mathrm{l}$ in waste water of ESIIC. The efficiency of (AC), $\mathrm{H}_{2} \mathrm{O}_{2}$, UV exposure and $\mathrm{UV} / \mathrm{H}_{2} \mathrm{O}_{2}$ are weak in the removal of organic pollution, however the COD values 34843, 33375, 33999 and $16000 \mathrm{mg} / \mathrm{l}$ after treatment. The recommended procedure for the removal of organic pollution using (AC) in the first step then $\mathrm{UV} / \mathrm{H}_{2} \mathrm{O}_{2}$ in the second step however the COD value reached to $980 \mathrm{mg} / \mathrm{l}$ after treatment.

Keywords: Chemical treatment, organic pollution, River Nile.

\section{INTRODUCTION}

Environmental pollution problems are considered the most serious problems that face mankind in the $20^{\text {th }}$ century. It is also, one of the most serious national problems which require great effects at all levels: industrial group, national and international (Marjonoric, 1990). This is especially true with respect to River Nile pollution because it serve as recipient of urban, rural and industrial waste water which contain frequently, hazards contaminants in high concentration (Abdo, 2002).

About 120 industrial activities and gas filling stations occupy nearly $1 \%$ of the total Cairo land and are diffusely located throughout the region (Platenburg et al., 1997). The major industries estimating in the region can be classified as shown in Table (1).

Table 1: Types of industries exists in the greater Cairo

\begin{tabular}{|c|c|}
\hline No. of factories & Type \\
\hline 23 & Chemical industries \\
\hline 27 & Textile and Spinning \\
\hline 7 & Metals \\
\hline 32 & Food Industries \\
\hline 29 & Engineering \\
\hline 9 & Mining \\
\hline
\end{tabular}

According to Helwan Waste Water Master Plan (1978), the industrial waste water discharge from Helwan (except El-Badrasheen area) amounts to about 41,314,000 cubic meter per annum. Shoubra El-Kheima area represents one of the highest concentrations of industry in Egypt. The industrial activities include metal production, food processing, detergents and soap manufacturing, textile finishing and paper pulp. Moreover, the electrical power plants use the River Nile water in cooling processes and recoiling water discharged into the Nile causing thermal pollution (Abdo, 2002). 
The discharged industrial waste water of 350 industries into the River Nile created numbers of new conditions which are noticed by comparing the pictures upstream and downstream the waste water discharge (El-Sharkawy, 2010).

Many treatment processes, such as chemical precipitation, evaporation, ion exchange, adsorption, electro dialysis and reverse osmosis, are currently used (El-Sharkawy, 2010). Among these methods, adsorption is promising and widely applied method due to its, low cost and effectiveness. Activated carbon is one of the most popular adsorbents for the removal of metals and organic pollutants from aqueous solutions (Abdo et al., 2010). Through the world other material have been used for the production of activated carbon such as Peanut skin, melon seed ,husks, stream, onionskin, tea leaves, line seed fiber and some other agriculture by-products (El-Sharkawy, 2010).

The objective of the present study is studying the factors affecting the uptake of organic pollutants from ESIIC waste water samples using activated carbon developed from locally available materials e.g. Rice straw by one-step steam pyrolysis, followed by advanced oxidation using $\mathrm{H}_{2} \mathrm{O}_{2} / \mathrm{UV}$ for removal of organic pollutant through the decrease in Chemical Oxygen Demand (COD)values.

\section{MATERIALS AND METHODS}

\section{Historical background of the area under investigation:}

According to EEAA (2009), Egyptian Sugar and Integrated Industries Company "ESIIC" is one of the affiliated companies of food industries holding companies. ESIIC has 8 sugar factories that crush annually over 10million tons of cane producing more than 1 million ton of white cane and refined sugar and 450,000 ton of molasses as by-products. The cultivated cane area reaches 325,000 feddans throughout all Upper Egypt governorates, mainly concentrated in El- Minya, Souhag, Qena and Aswan. Approximately 45\% of the molasses are manufactured by ESIIC to useful bio-products in biochemical factories belonging to ESIIC; Hawamdia Dsitillery Factory (HDF), Hawamdia Chemical Factory (HCF) and Abu Korkas Distillery Factory (AKFD). Molasses, the main raw material for biological products, contain sugars, minerals and organic non-sugar compounds. The sugars in molasses are fermented in different processes to ethyl alcohol, yeast, acetone, butanol and $\mathrm{CO}_{2}$ products. After separating these products in pure form, the waste residuals are collectively called Vinasse. The Vinass liquor (VL) causes a serious polluting problem, due to its high hydraulic, biological, mineral loads, high temperature degrees and violating brown color. The daily average volume of Vinasse all over the year is 2550 ton. Violating parameters of Vinasse liquor: Color: dark brown, BOD: 22000mg/l, COD: $44400 \mathrm{mg} / \mathrm{l}$ and ash (on dry materials): $13000 \mathrm{mg} / 1$.

Vinasse has serious impact on water quality of the River Nile, resource consumption and worker safety if not environmentally managed. As world wide experience has shown in adequate consideration of the environmental impact of alcohol production can lead damage. On the other hand, the major progress has been made by the industry in last four decades, and modern technologies for the treatment of effluents have greatly reduced their volume and impact. Great awareness about the importance of environmental risk management was based upon the economic development, health and quality of life, using the (4R) technical package (Reduce-Reuse-Recovery).

\section{Sampling program:}

Sub surface water samples were collected during four sampling campaigns at three sites of ESIIC along the River Nile. The three sites (I, II and III) are:

I: From the River Nile before $2 \mathrm{~km}$ of ESIIC (upstream).

II: Discharged point of ESIIC waste water into the River Nile.

III: The next site after the ESIIC discharged into the River Nile (downstream). 


\section{Water analysis:}

\section{Field measurements:}

The electrical conductivity (EC) of water sample $(\mu \mathrm{S} / \mathrm{cm})$, temperature $\left({ }^{\circ} \mathrm{C}\right)$, and $\mathrm{pH}$ values were measured in the field using Hydrolab, Model "Multi 340I/SET". Alkalinity $\mathrm{CO}_{3}{ }^{2-}$ and $\mathrm{HCO}_{3}^{-}$were measured titrimetrically on spot, where samples were titrated against standard $\mathrm{H}_{2} \mathrm{SO}_{4}(0.025 \mathrm{~N})$ using phenol phethalin and methyl orange indicators. Also, dissolved oxygen (DO) content was determined by Azide modification method as specified in APHA (2008).

\section{Laboratory measurements:}

Water samples were analyzed for all selected variables according to procedures specified in the standard method of American Public Health Association APHA (2008). Total solid (TS) was measured by evaporating a known volume of well mixed sample at $105^{\circ}$ C.Chemical oxygen demand (COD) was performed by refluxing flask and $\mathrm{K}_{2} \mathrm{Cr}_{2} \mathrm{O}_{7}$ oxidation and Biochemical oxygen demand (BOD) by 5 days incubation method. $\mathrm{Cl}^{-}$was determined by argenometric method and $\mathrm{SO}_{4}{ }^{-2}$ by turbidity method. $\mathrm{Na}^{+}$and $\mathrm{K}^{+}$were measured directly using flame photometer Model "Jenway PFP, UK". $\mathrm{Ca}^{+2}$ and $\mathrm{Mg}^{+2}$ were determined by EDTA titrimetric method. Concentrations of $\mathrm{NO}_{2}{ }^{-}, \mathrm{NO}_{3}{ }^{-}, \mathrm{NH}_{3}$, Orthophosphate (ortho-P) and reactive silicate in water were determined using the colorimetric techniques with formation of reddish purpleazo-dye, Cd-reduction, Phenate, stannous chloride reduction and molybdo silicate method, respectively. Total Phosphorous (total-P) was measured as reactive phosphate after ammonium persulphate digestion technique.

\section{Preparation of the active carbon from rice straw:}

One- step steam pyrolysis of rice straw:

The fluidized bed reactor was heated until the bed temperature reach to $150^{\circ} \mathrm{C} .0 .5 \mathrm{Kg}$ of dried rice straw was injected into the reactor and subjected to heating rate of $150^{\circ} \mathrm{C} / 10 \mathrm{~min}$ under inert environment of nitrogen. The flow rate of nitrogen used was sufficient to provide good mixing of the rice straw within the reactor $(300 \mathrm{ml} / \mathrm{min})$. When the temperature of the furnace reach to $350^{\circ} \mathrm{C}$, the steam produced by steam generator entered the reactor at a rate of approximately $5 \mathrm{~cm}^{3} / \mathrm{min}$ and at this temperature heating was continue up to final temperature of $750^{\circ} \mathrm{C}$, holds at this temperature for one hour. After the treatment, the sample was left to cool down and the steam flow is interrupted at temperature $250-300^{\circ} \mathrm{C}$, then the sample was drown from the reactor and weighed. This gives adsorbent two, C-2 (EL-Sharkawy, 2001).

\section{Removal of organic pollutants from ESIIC waste water:}

The target was to removal of organic pollutants and to achieve the permissible levels of COD in ESIIC effluent using adsorbent C-2. In this concern, four trials were applied:

1- Effect of adsorbent mass (C-2)

2- Effect of $\mathrm{H}_{2} \mathrm{O}_{2}$

3- Using UV exposure

4- Using $\mathrm{UV} / \mathrm{H}_{2} \mathrm{O}_{2}$

A Hewlett Pack'rd Diode array spectrophotometer (Model 8451 A) was used to measure the UV/Vis absorbance for raw and treated water samples. A micro-processor $\mathrm{pH}$ meter HANNA (ModelHI-9321) was used for $\mathrm{pH}$ measurements. A water bath shaker of American Optical Corporation (Model Buffalo, Newyork) was used for all the adsorption experiments.

\section{RESULTS AND DISCUSSION}

\section{Water quality of the River Nile studied area at ESIIC:}

The water quality is largely affected by natural processes (weathering and soil erosion) as well as anthropogenic impact (municipal and industrial waste water discharge). The anthropogenic discharges represent aconstant polluting source, whereas surface runoff is a seasonal phenomenon largely affected by climatic conditions (Najafpour et al., 2008).

In view of the Table (2) we can declare that the physico-chemical parameters of water quality increased at station II and slightly increased at III and decreased values at station I. The mean 
concentration values of TS; $3577 \mathrm{mg} / 1, \mathrm{BOD} ; 2403 \mathrm{mg} / 1$ and COD; $3558 \mathrm{mg} / 1$ respectively. This is mainly attributed to the waste water of ESIIC included great amount of suspended matter and other organic pollutants discharged intothe River Nile at this station.Also, the increase in water temperature $\left(40{ }^{\circ} \mathrm{C}\right)$ at station II was related to the thermal pollution discharged from ESIIC into the River Nile at this area. On the other hand, all physical and chemical parameters concentration values were recorded at stations I \& III are within the permissible limits of waters quality standard values (AWWA, 1991). Therefore, the main problem is represented in the high values of COD at station II, that related to the effluent effects of ESIIC and the target was to improve the efficiency of removal of organic pollutions matter in ESIIC (COD; $36294 \mathrm{mg} / \mathrm{l})$.

Table 2: The mean values of water quality parameters of the area under investigation

\begin{tabular}{|c|c|c|c|c|}
\hline \multicolumn{2}{|c|}{$\begin{array}{lc} & \text { Stations } \\
\end{array}$} & \multirow[t]{2}{*}{ I } & \multirow[t]{2}{*}{ II } & \multirow[t]{2}{*}{ III } \\
\hline \multicolumn{2}{|c|}{ Parameters } & & & \\
\hline \multirow{5}{*}{$\begin{array}{l}\text { Physical } \\
\text { parameters }\end{array}$} & Air Temp ${ }^{\circ} \mathrm{C}$ & 21 & 23 & 24 \\
\hline & Water Temp ${ }^{\circ} \mathrm{C}$ & 20 & 32 & 30 \\
\hline & Transp. $\mathrm{cm}$ & 85 & 40 & 43 \\
\hline & $\mathrm{EC} \mu \mathrm{S} / \mathrm{cm}$ & 400 & 617 & 501 \\
\hline & TS $\mathrm{mg} / \mathrm{l}$ & 264 & 3577 & 669 \\
\hline \multirow{18}{*}{$\begin{array}{l}\text { Chemical } \\
\text { parameters }\end{array}$} & $\mathrm{pH}$ & 8.3 & 7.5 & 7.8 \\
\hline & $\mathrm{DO} \quad \mathrm{mg} / \mathrm{l}$ & 10.0 & 7.0 & 8.0 \\
\hline & BOD $\mathrm{mg} / 1$ & 5.0 & 2463 & 36 \\
\hline & COD mg/l & 19.0 & 3558 & 125 \\
\hline & $\mathrm{CO}_{3}{ }^{-2} \mathrm{mg} / 1$ & 7.8 & nil & 3.8 \\
\hline & $\mathrm{HCO}_{3}^{-} \mathrm{mg} / 1$ & 214 & 300 & 236 \\
\hline & $\mathrm{SO}_{4}{ }^{2-} \mathrm{mg} / \mathrm{l}$ & 28 & 46 & 36 \\
\hline & $\mathrm{Cl}^{-} \mathrm{mg} / \mathrm{l}$ & 27 & 27 & 25 \\
\hline & $\mathrm{Ca}^{+2} \mathrm{mg} / \mathrm{l}$ & 33 & 104 & 39 \\
\hline & $\mathrm{Mg}^{+2} \mathrm{mg} / \mathrm{l}$ & 15 & 25 & 16 \\
\hline & $\mathrm{Na}^{+} \mathrm{mg} / \mathrm{l}$ & 34 & 35 & 33 \\
\hline & $\mathrm{K}^{+} \mathrm{mg} / \mathrm{l}$ & 5 & 7 & 6 \\
\hline & $\mathrm{NO}_{2}^{-} \mu \mathrm{g} / \mathrm{l}$ & 14 & 17 & 17 \\
\hline & $\mathrm{NO}_{3}{ }^{-} \mu \mathrm{g} / \mathrm{l}$ & 40 & 59 & 38 \\
\hline & $\mathrm{NH}_{4}^{+} \mu \mathrm{g} / \mathrm{l}$ & 520 & 3250 & 2090 \\
\hline & $\mathrm{SiO}_{3}^{-} \mathrm{mg} / \mathrm{l}$ & 4.3 & 5.89 & 5.27 \\
\hline & $\mathrm{PO}_{4}{ }^{3-} \mu \mathrm{g} / 1$ & 85 & 546 & 137 \\
\hline & TP $\mu \mathrm{g} / 1$ & 135 & 832 & 216 \\
\hline
\end{tabular}

\section{Characterization of prepared activated carbon:}

Some physical and chemical properties of the prepared activated carbon are shown in Table (3). In this concern, there are two types of densities associated with activated carbon called apparent and packed (bulk) density.

Table 3: Physical and chemical properties of the prepared activated carbon (C-2)

\begin{tabular}{|c|c|c|}
\hline parameters & unit & C-2 \\
\hline Apparent density & $\mathrm{g} / \mathrm{ml}$ & 0.21 \\
\hline Bulk (packed) density & $\mathrm{g} / \mathrm{ml}$ & 0.28 \\
\hline Ash content & $\%$ & 40 \\
\hline BET- surface area & $\mathrm{m}^{2} / \mathrm{g}$ & 63 \\
\hline Pore volume & $\mathrm{CC} / \mathrm{g}$ & 1.35 \\
\hline Pore diameter & $A^{\circ}$ & 16.5 \\
\hline Methylene blue (MB) index & $\mathrm{mg} / \mathrm{g}$ & 41 \\
\hline $\mathrm{pH}$ & & 9.07 \\
\hline
\end{tabular}

The apparent density of a solid is defined as the mass of unit volume of the carbon particle indicating its pore system. While in bulk density, is defined as the mass of unit 
volume of the sample including both the pore system and the voids among the particles. The American water works Association (AWWA, 1991) has set a lower limit on the bulk density at $0-25 \mathrm{~g} / \mathrm{ml}$ GACs to be of particle use. The high bulk density is explained by the high lignin of precursors.

The ash content of the carbon is the residue that remains when the carbonaceous material is burned off. The ash content of the adsorbent depends on the chemical composition of the raw material (mainly inorganic compounds) and the degree of carbonization (Zanzi, 2001). The specific surface area was estimated by applying the BET- equation to get the BETsurface area, the total pore volume, $\mathrm{V}_{\mathrm{p}}$ from nitrogen held as liquid at relative pressure $\mathrm{p} / \mathrm{p}_{\mathrm{o}}=$ $0-95$, and an average pore radius from the empirical relation $\mathrm{r}=2 \mathrm{~V}_{\mathrm{p}} / \mathrm{S}_{\mathrm{BET}}$ (Villar-Rodile et al., 2002).

Table (3) indicates that the adsorbent C-2 has lower surface area $\left(63 \mathrm{~m}^{2} / \mathrm{g}\right)$, higher pore volume $(1.35 \mathrm{cc} / \mathrm{g})$ and the diameter $\left(16.5 \mathrm{~A}^{\circ}\right)$. The dye adsorption $(\mathrm{MB})$ was used to determine the capacity of the activated carbon to adsorb molecules of a particle size (Yenisory-Karakas et al., 2004); the uptake of MB by C-2 (41/ mg/g) is acceptable. The $\mathrm{pH}$ measurement it is well established that steam activation at high temperatures $\left(800-1000^{\circ} \mathrm{C}\right)$ from alkalinoxide, which have chromene and pyron type structure (Pereira et al., 2003). The most activated carbons are usually alkalin $(\mathrm{pH} \approx 8)$ and probably the high ash content might additionally raise the basicity e.g.C-2.

\section{Treatment of organic matter of ESIIC waste water:}

In this concern, advanced oxidation process involving hydroxyl radicals $\mathrm{OH}^{-}$, represent anew treatment concept and have gained increasing interest in treatment of industrial and drinking wastewater to remove organic contaminants. So, four trials were applied to get the recommended procedure to decrease the organic pollutants and achieve the permissible level of COD in ESIIC effluents.

$1^{\text {st }}$ trial "C-2 mass effect":

The effect of adsorbent mass was tested in removal of organic pollutants matter due to COD values. As shown in Table (4), as the adsorbent amount of C-2 Activated Carbon(AC) increases, the \% Rvalues increases.

Table 4:\% R of organic pollutants related to COD values in the ESIIC effluents using C-2.

\begin{tabular}{|c|c|c|c|c|}
\hline Serial no. & $\begin{array}{c}\text { C-2AC (Adsorbent } \\
\text { mass) }\end{array}$ & $\begin{array}{c}\text { Initial concentration } \\
\text { Of COD C }\end{array}$ & $\begin{array}{c}\text { Final concentration } \\
\text { of } \mathrm{COD} \mathrm{Ce} 2\end{array}$ & $\% \mathrm{R}$ \\
\hline 1 & 19/e C-2 AC & \multirow{5}{*}{36294} & 36058 & 0.65 \\
\hline 2 & 29/e C-2 AC & & 35791 & 1.38 \\
\hline 3 & $39 / \mathrm{e} \mathrm{C}-2 \mathrm{AC}$ & & 35295 & 2.75 \\
\hline 4 & $49 / 1 \mathrm{C}-2 \mathrm{AC}$ & & 34964 & 3.66 \\
\hline 5 & 59/e C-2 AC & & 34843 & 4.00 \\
\hline
\end{tabular}

However, asteady-state condition was apparent indicating that $5 \mathrm{~g} / 1$ of C-2 AC increases the $\% \mathrm{R}$ achieved $4 \%$ removal of organic matter pollutants in ESIIC effluents. Excess of AC will inhibit good mixing and in turn prevent the organic matter pollution to reach all the AC particles i.e. of no use (Niragu and Simmons, 1994).

$2^{\text {nd }}$ trial " $\mathrm{H}_{2} \mathrm{O}_{2}$ effect":

The presence of $\mathrm{H}_{2} \mathrm{O}_{2}$ has agreat influence in the reduction of organic pollution concentration in waste water. Moreover, it is necessary to decide the amount of $\mathrm{H}_{2} \mathrm{O}_{2}$ to fulfill the lowest possible value of COD. This is due to the much higher $\mathrm{H}_{2} \mathrm{O}_{2}$ concentration will be (1) economically undesirable (Shen et al., 1996) and (2) scavengers for hydroxyl radical. The residual of $\mathrm{H}_{2} \mathrm{O}_{2}$ in solution was determined by the $\mathrm{KI}$ titration method.

Figures (1\&2) show the ratio between $\mathrm{H}_{2} \mathrm{O}_{2} /$ Slope (v/v) and contact time to achieve the maximum $(\% \mathrm{R})$ of COD. 


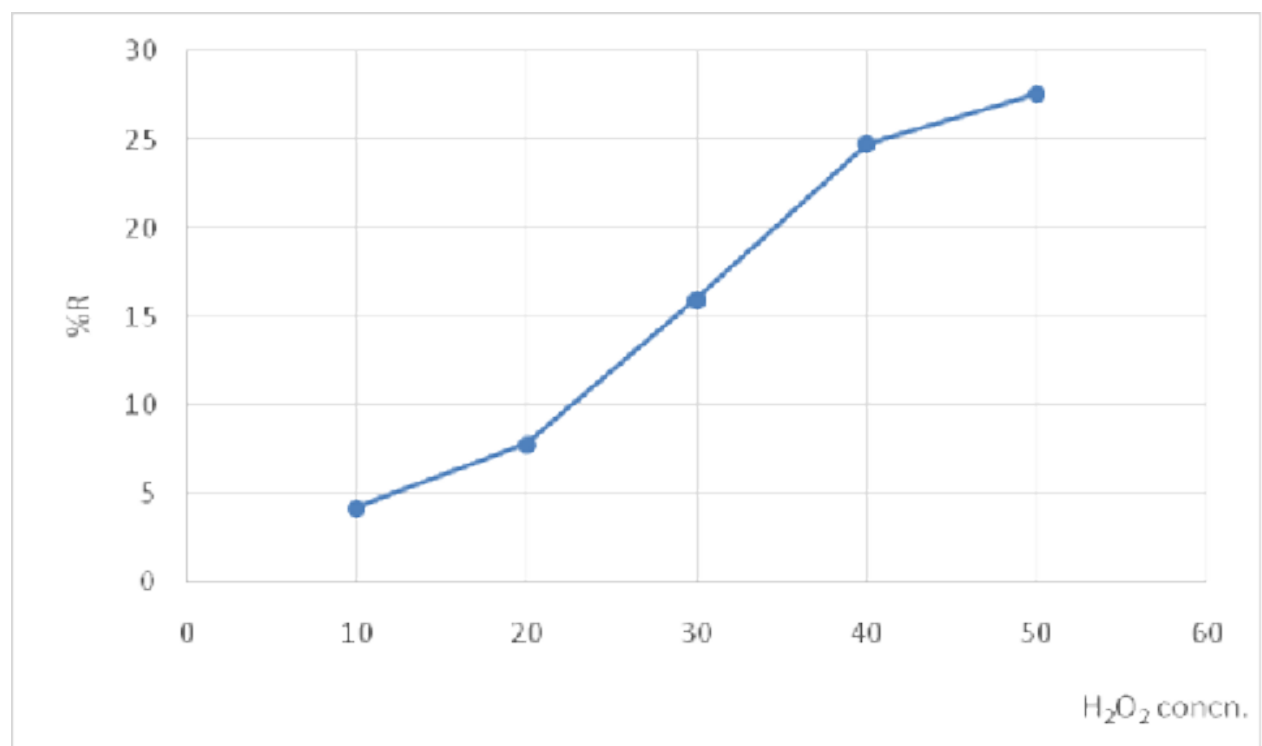

Fig. 1: \%R of the COD in the ESIIC effluents using $\mathrm{H}_{2} \mathrm{O}_{2}$ (various concentrations).

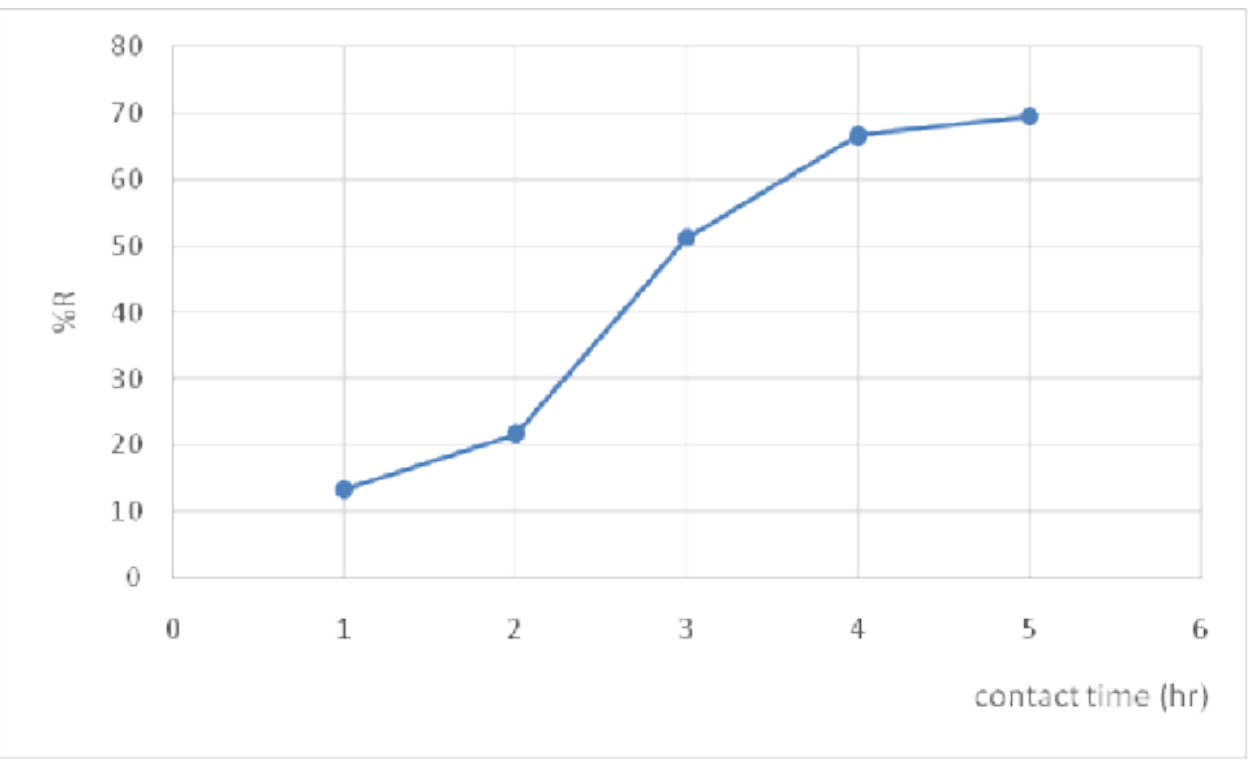

Fig. 2: \% $\mathrm{R}$ of the COD in the ESIIC effluents using $\mathrm{H}_{2} \mathrm{O}_{2}$ (various contact time)

\section{$3^{\text {rd }}$ trial "UV exposure"}

The presence of UV light has an influence on the reduction of the organic pollution concentration in wastewater. But, it is limited without presence of an $\mathrm{H}_{2} \mathrm{O}_{2}$ full file the lowest possible value of COD shown in Fig. (3). 


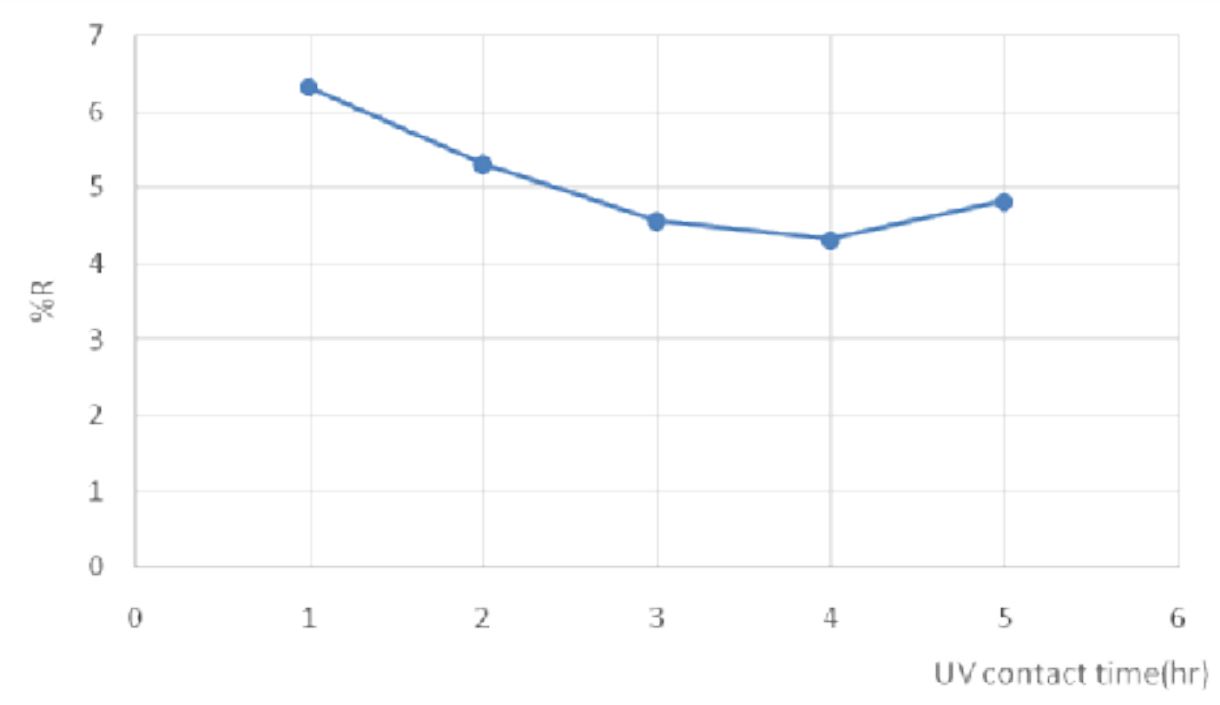

Fig. 3: \%R of the COD in the ESIIC effluents using UV exposure (various contact time).

\section{$4^{\text {th }}$ trial "UV/ $\mathrm{H}_{2} \mathrm{O}_{2}$ effect"}

In the presence of $\mathrm{H}_{2} \mathrm{O}_{2}$ photocatalytic and radiation with $\lambda>300 \mathrm{~nm}$, the radiation was as follows:

$\mathrm{H}_{2} \mathrm{O}_{2}+\mathrm{UV} \longrightarrow 2 \mathrm{OH}^{-}$

The reduction of the COD in the ESIIC effluentswas rapid; there was a $97.2 \%$ reduction of COD using UV system after one hour exposure and reaction with $30 \% \mathrm{H}_{2} \mathrm{O}_{2}$ as shown in Fig. (4).

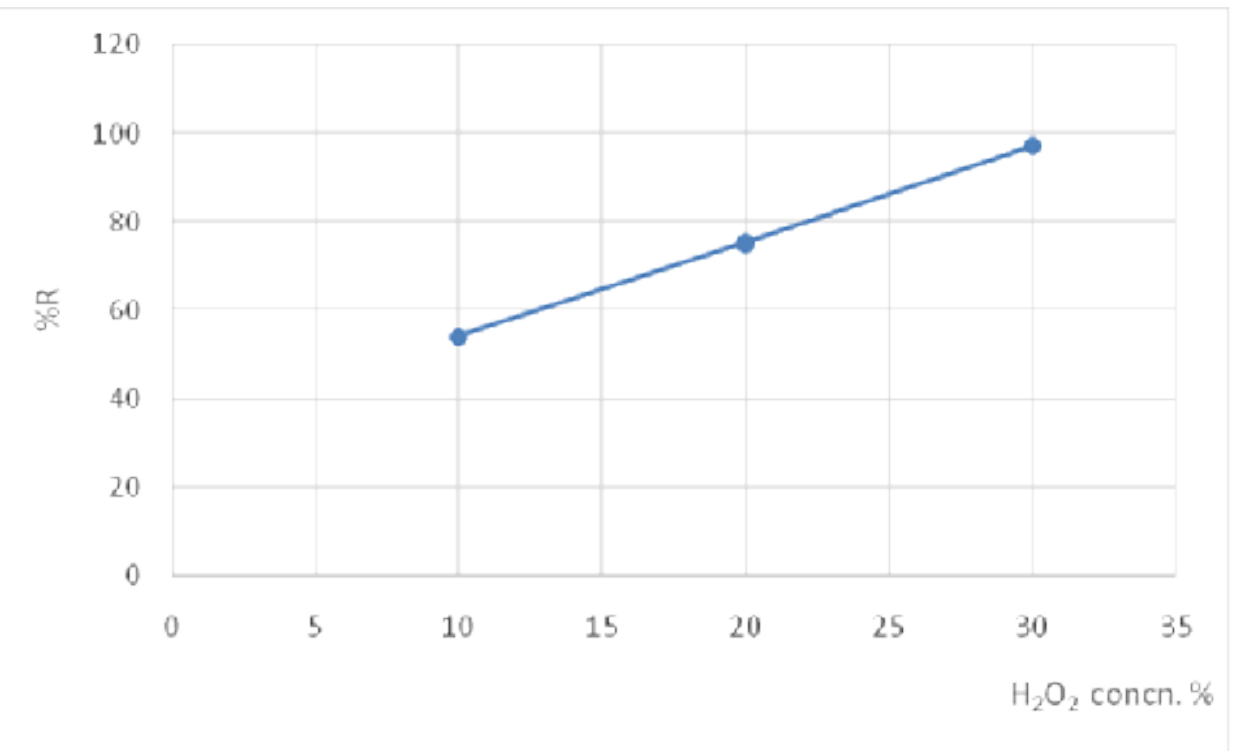

Fig. 4: \% R of the COD in the ESIIC effluents using $\mathrm{UV} / \mathrm{H}_{2} \mathrm{O}_{2}$

\section{CONCLUSION AND RECOMMENDATION}

In this concern, treatment of wastewater by mixing with $\mathrm{C}-2$ activated carbon was assessed, followed by advanced oxidation with UV and $\mathrm{H}_{2} \mathrm{O}_{2}$. As a measure of extent treatment we used the \% removal at chemical oxygen demand (COD) before and after the treatment. 
Based on the results of the experiments, the amount of AC C-2 $(5 \mathrm{~g} / 1)$ was used. In case of the $2^{\text {nd }}$ step (photo-oxidation using $\mathrm{UV} / \mathrm{H}_{2} \mathrm{O}_{2}$ ), the ratio of the $\mathrm{H}_{2} \mathrm{O}_{2}$ to the contaminate was 3:10 and the exposure time required for complete degradation was one hour. So,

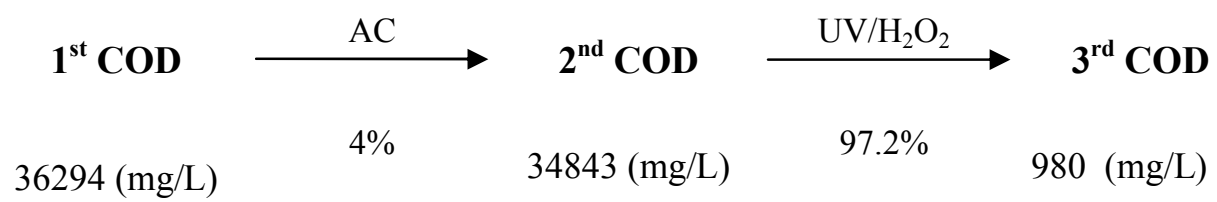

On the basis of the adsorption and advanced oxidation process (AOPs) studies, apilot plant for the treatment of organic pollutions in ESIIC effluents can be established to achieve the permissible level of COD. We can conclude that the ESIIC wastewater carrying heavy load of organic pollution is mostly has serious effect on the River Nile water quality, and we recommended applying the present chemical treatment procedure to remove this organic pollutants from ESSIC effluents to safe the River Nile water quality at this area.

\section{REFERENCES}

Abdo, M.H. (2002). Environmental studies on Rosetta branch and some chemical applications at area extend from EL-Kanater EL-Khyria to kafr EL-zayat city. ph. D. Thesis, Fac. Sci., Ain Shams Unv., Egypt.

Abdo, M. H; Daifullah, A. A; Moustafa, M.E; Amin, A. S. and Mohamed, F. M. (2010). Evaluation quality and chemical treatment of the drinking ground water in the Qalubia Governorate, Egypt. Egypt J. Anal. chem., 19: 64-69

APHA (2008). Standard Methods for the Examination of Water and Waste water. $21^{\text {st }}$ Edn., published by American Public Health Association, Washington, DC,USA.

AwwA (American Water Works Association) (1991). Standards for Granular Activated Carbon, American Water Works Association, ANSI/AWWA B604-90 Denerver, Co

EEAA (Egyptian Environmental Affairs Agency), HDF (2009). Auditing project report, Vinasse concentrate project Hawamdia Distillery Factory (H.D.F) Agency-ESIIC

El-Sharkawy, E. A. (2001). Adsorption of textile dyes onto activated carbons synthesized from solid waste: Decolorization power in relation to surface properties. Ads. Sci. Technol., 19(10): 795-780

El-Sharkawy, M. H. (2010). Quantitative assessment and treatment of some industrial pollutants along the River Nile at Giza region.Master Sci., Benha Univ.

Marjonoric , A. (1990). Fish gill structural changes induced by toxicant and other irritants: A statistical Review, Can. j. Fish. Aquat. Sci., 42 (4): 630-648

Najafpour, S.; Alkarkhi, A.; Kadir F.M and Najfpour, G.D. (2008). Evaluation of spatial and temporal variation in river water quality. Int. J. Environ. Res., 2(4):349-358

Niragu, J. O. and Simmons, M. (1994). Environmental oxidants, John Wiley \& sons, Inc, USA. 534pp.

Pereira, M. F. R.; Soares, S. F.; Orf, J. J. M. and Figueiredo, J. L. (2003). Carbon, 41: $811-821$

Platenburg, R. J.; Hoencamp, T. and El-Arabi, N. E. (1997). Soil quality management at industrial sites: Dutch experience relevant for Egyptian context. $1^{\text {st }}$ intenational conference and trade fair on environmental management and technologies, 2: 205-210

Shen, Y.; Ku Y. and kuen-Chyrlee (1996).Toxical. Environ. Chem., 51(51): 21-25

Villar-Rodile S.; Denoye R.; Rouquero J.; Martinez-Alonso A. and Tascon J. M. D. (2002). Colloid and Interface Sci., 252: 169-176.

Yenisoy- Karaka; Aggun, A.; Gumes, M. and Tahtasakal, E. (2004). Carbon, 42:477- 484.

Zanzi R., (2001). Pyrolysis of Biomass: (Rapid Pyrolysis at high temperature and slow pyrolysis for activated carbon preparation). Ph.D. Thesis, Stockholm Univ. 


\section{ARABIC SUMMARY}

التقييم والمعالجة الكيميائية للتلوث العضوى المنصرف فى نهز النيل - دراسة حالة

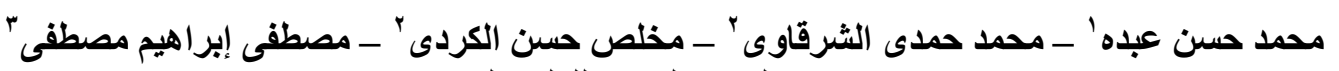

$$
\begin{aligned}
& \text { 1 - المعهد القومي للعلوم البحار } \\
& \text { r- با مصلحة الكيمياء } \\
& \text { ب- ملية العلوم - جامعة بنهاء }
\end{aligned}
$$

تهدف هذه الدراسة الي تقيم وتأثير الملوثات العضوية علي جودة مياه نهر النيل وكيفية عمل معالجة

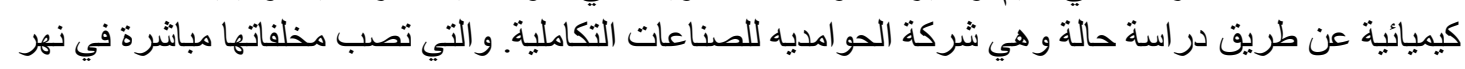

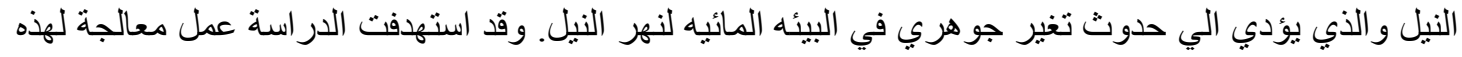

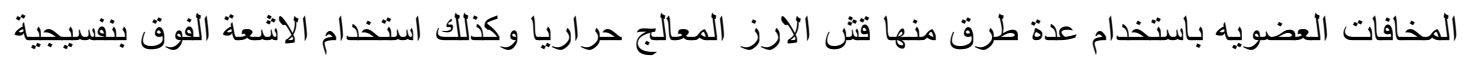

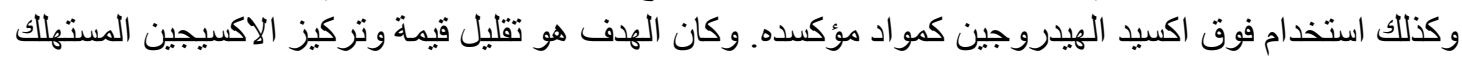

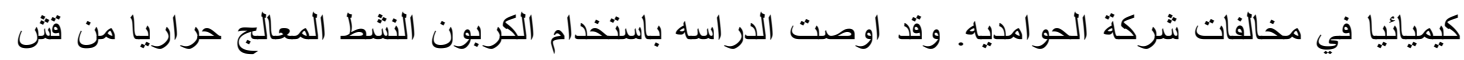

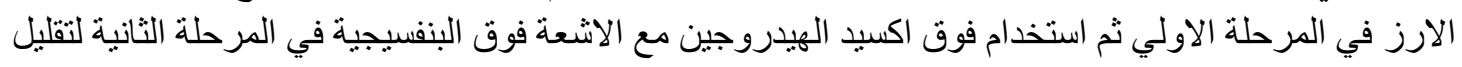
قيمة وتركيز الاكسيجين المستهلك كيميائيا. 